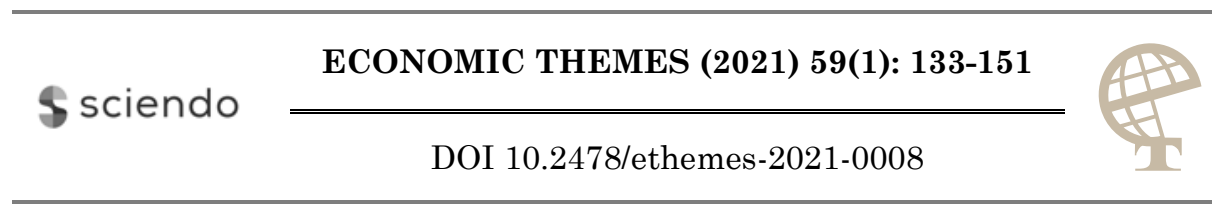

\title{
ANALYSIS OF NON-PERFORMING LOANS' DETERMINANTS IN THE BANKING SECTOR OF THE REPUBLIC OF SERBIA
}

\author{
Kristijan Ristić \\ Faculty of Business and Law, Union University Nikola Tesla, Belgrade \\ $\triangle$ kristijanristic.fpim@yahoo.com
}

Mirjana Jemović

Faculty of Economics, University of Niš, Republic of Serbia

$\triangle$ mirjana.jemovic@eknfak.ni.ac.rs

UDC

336.77

(497.11)

Original

scientific

paper

Received:

25.11.2020

Accepted:

28.12.2020

\begin{abstract}
After the financial deregulation that marked the last two decades of the 20th century, banks lost their monopolistic position and faced a number of competitors on the financial market. Fighting for their market share, banks began to grant loans under more relaxed terms. This policy increased the share of non-performing loans (NPLs) and ultimately increased credit risk in the banking sector. The share of non-performing loans in total loans indicates the quality of bank assets, so their analysis and trend are an important parameter in assessing the stability of the banking and overall financial sector. The paper aims to analyze the NPL trend in the banking sector of the Republic of Serbia in the period from 2010-2019 and, thus, identify determinants that significantly affect the extent of credit risk. The research uses vector autoregressive model (VAR), and the results confirm that gross domestic product, inflation, unemployment, return on total assets (ROA), cost efficiency, capital adequacy ratio, and income diversification affect NPLs. The analysis shows that the level of nonperforming loans depends on a number of factors, both macroeconomic and bank-specific, which regulatory authorities must keep in mind when assessing the credit risk that banks face.
\end{abstract}

Keywords: NPL, determinants, VAR, banking sector in RS

JEL classification: G21, G17

\section{Introduction}

Being part of the financial system, banks have been given an exclusive license to perform deposit-lending operations. Bearing in mind that the main source of bank income is credit, banks focus their activities not only on adequate assessment of 
credit requirements (credit analysis), but also on monitoring loan-related liabilities. Monitoring the level and trend of non-performing loans (NPLs) is of great importance for noticing possible deterioration in the quality of the loan portfolio, which ultimately compromises the bank's performance, but also reduces its ability to serve the economy and citizens with loans. The link between NPLs in the banking sector and economic recovery is much more direct when one considers the fact that economic recovery and rising economic growth rates reduce NPLs. The Basel Committee on Banking Supervision (BCBS) recognizes credit risk as the first and most significant risk burdening banking operations. Among other things, the occurrence of other types of risk is mostly materialized through credit risk. For these reasons, credit risk management has been in the BCBS list of priorities since its establishment. A high-level group on non-performing loans, formed in July 2015, confirms the importance of resolving the NPL issue. Composed of ECB officials and national regulatory authorities, the group's task is to develop guidelines, recommendations and approaches to managing NPLs for European banking groups to apply in practice (ECB, 2017).

The global financial crisis, which, due to the inability to collect approved mortgage loans, brought huge losses in banks' balance sheets, made us focus on NPL analysis over a ten-year period after. After the conceptual definition of NPLs, the paper presents their trend in the banking sector of the Republic of Serbia in the period from 2010-2019. The second part of the paper focuses on the impact of the selected variables on NPLs in the banking sector of the Republic of Serbia in the observed period. Research relies on the VAR model, applied to the quarterly data taken from the Banking Supervision Report of the National bank of Serbia.

\section{Conceptual definition and analysis of the non-performing loan trend in the banking sector of the Republic of Serbia}

To define NPLs, we first look at the definition used by the ECB and European supervisors, according to which a loan is considered non-performing if there are indications that the borrower will not repay the loan due to financial difficulties or is more than 90 months late. From the bank's point of view, these loans are classified as "non-performing" or "bad debt" (ECB, 2020). According to the NBS methodology, "NPL means the balance of the total remaining debt of each individual loan (including the amount of arrears): a) where debtor is late with principal or interest repayment for 90 days or more from the initial maturity; b) where the quarterly interest (and higher) is attributed to debt, capitalized, refinanced or deferred; c) where debtor is less than ninety days late, but the bank considers the debtor's ability to repay the debt has deteriorated and questions full repayment" (NBS, 2020, p. 18).

The key position of banks in the banking sector of Serbia and the dominant share of credits in total lending make the banking sector significantly exposed to 
credit risk. In order to identify possible problems in the collection of receivables, among other things, it is necessary to monitor the level and trend of non-performing loans. The global financial crisis has increased NPLs, especially in the period after 2009 (more on this in: Račić \& Barjaktarović, 2016), which made us focus the analysis on the ten-year period after. In order to obtain a more complete picture of the NPL level and trend, and there being data on the share of NPLs in total loans at the level of individual banks in Serbia, the analysis focuses on data taken from the Banking Supervision Report for the IV quarter of 2010-2019 (Table 1).

Table 1: Trend of total loans, NPLs and the share of NPLs in total loans of the banking sector of the Republic of Serbia in the period 31.12.2010.-31.12.2019.

\begin{tabular}{||c|c|c|c||}
\hline Year & $\begin{array}{c}\text { Total lending } \\
\text { RSD bn }\end{array}$ & $\begin{array}{c}\text { Total Non- } \\
\text { performing loans } \\
\text { RSD bn }\end{array}$ & $\begin{array}{c}\text { The share of NPLs } \\
\text { in the total loans } \\
(\%)\end{array}$ \\
\hline 31.12 .2010$. & 1661,3 & 273.5 & 16.46 \\
\hline 31.12 .2011$. & 1837.1 & 342.7 & 18.65 \\
\hline 31.12 .2012$. & 1923.2 & 365.8 & 19.02 \\
\hline 31.12 .2013$. & 1880.7 & 395.3 & 21.02 \\
\hline 31.12 .2014$. & 1860.7 & 421.3 & 22.64 \\
\hline 31.12 .2015$. & 1885.2 & 424.6 & 22.52 \\
\hline 31.12 .2016$. & 1972.8 & 345.8 & 17.53 \\
\hline 31.12 .2017$. & 2053.6 & 204.9 & 9.98 \\
\hline 31.12 .2018$. & 2267.2 & 130.6 & 5.76 \\
\hline 31.12 .2019$. & 2459.6 & 101.4 & 4.12 \\
\hline
\end{tabular}

Source: (NBS, 2011; 2013) (NBS, 2014-2019)

Absolute values of total lending in the observed period show growth trend. Although 2013 and 2014 record slight decline, after 2015, total lending again takes a growth trend. When observing the NPLs in the observed period, it is not possible to unambiguously determine their direction. In addition, gross NPLs in some years do not have the same direction as total lending. Specifically, until the end of 2015, absolute value of non-performing loans increased despite a drop in total loans over a consecutive three-year period (2013-2015). After that, the absolute value of gross non-performing loans decreases, despite the increase in total loans. The decrease in gross NPL is mostly due to direct write-offs, assignments and sales of balance sheet receivables, but also collection of receivables. The following figure shows the ratio of total and non-performing loans in the banking sector of the Republic of Serbia according to the data for the IV quarter of the 2010-2019 period.

Monitoring the share of NPLs in total loans (non-performing loan ratio at the banking sector level) gives a more complete insight into credit risk exposure. Figure 2 shows its trend, expressed as a percentage of the share of NPLs in total approved loans. 
Figure 1: Trend of total and non-performing loans in the Republic of Serbia on 31.12. in the period 2010-2019

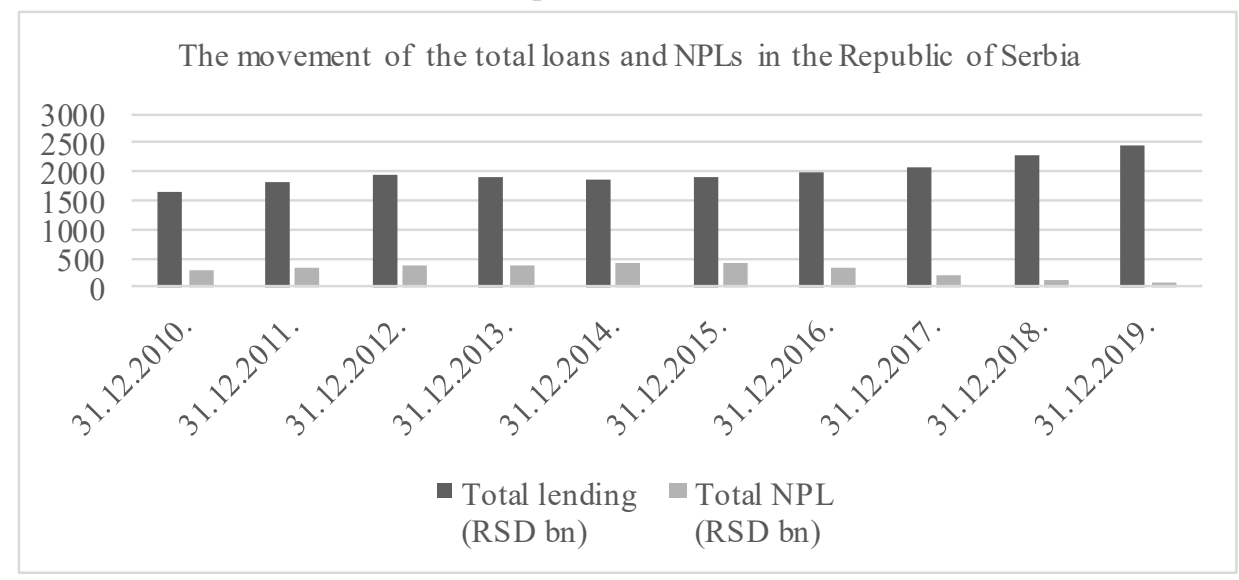

Source: (NBS, 2011; 2013) (NBS, 2014-2019)

Figure 2: Non-performing loan ratio at the banking sector level on 31.12. in the period 2010-2019

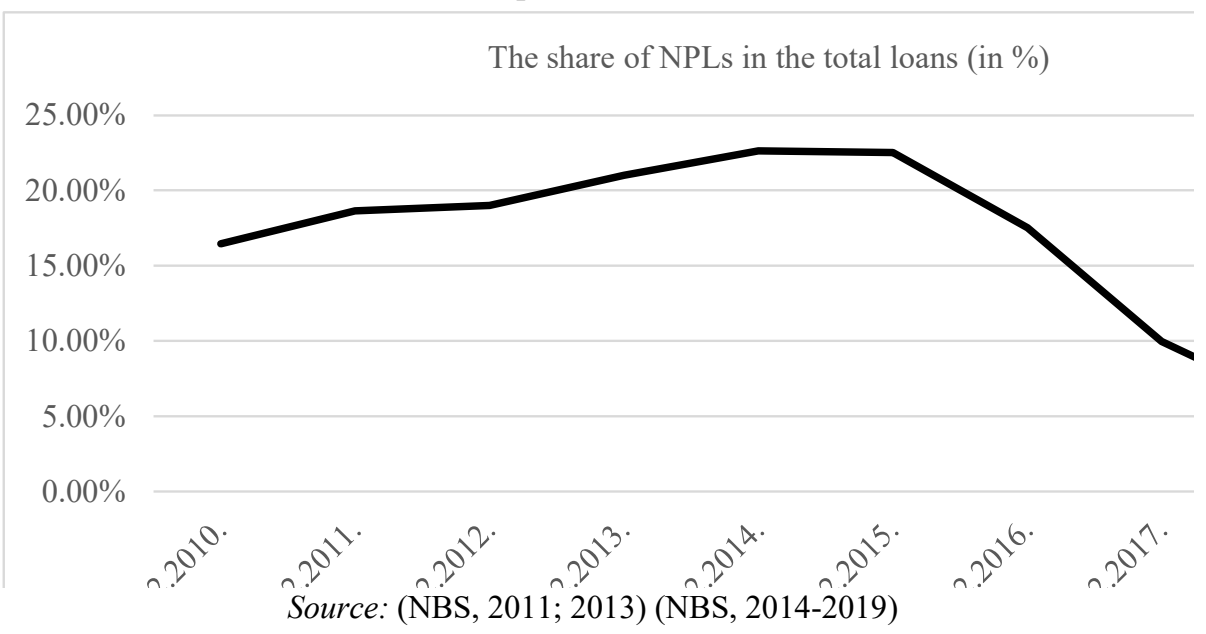

Rise in the share of non-performing in total loans at the sector level was there until the end of 2015. Specifically, the share of NPLs in total approved loans was $16.46 \%$ at the end of 2010 , with a constant increase from year to year by an average of 2 percentage points, and at the end of 2015 this share was as much as $22.64 \%$. After that, there was a downward trend in the share of NPLs in total loans granted at the sector level compared to the end of the previous year, as follows: at the end of 
2016 by almost 5 percentage points; at the end of 2017 by 7.5 pp; at the end of 2018 by 4.2 p.p. and at the end of 2019 by 1.6 p.p. (Association of Serbian Banks, 2017).

In addition to the analysis of NPL trend, the assessment of a bank's exposure to credit risk requires additional analysis of NPLs in relation to value adjustments, regulatory provisions and capital, which can ultimately assess the banking sector's ability to absorb losses resulting from NPLs. In any case, NPLs generate huge losses for individual banks and the sector as a whole, as a result of which numerous studies focus on identifying the determinants that lead to the approved loan becoming "non-performing" or "bad". In the following text, we analyze credit risk determinants in the banking sector of the Republic of Serbia.

\section{Analysis of credit risk determinants in the banking sector of the Republic of Serbia}

Literature offers numerous factors that stand out as NPL determinants, from macroeconomic and institutional factors to bank-specific ones (Nikolopoulos \& Tsalas, 2017). Among macroeconomic determinants, we monitor the impact of economic growth, gross domestic product (GDP), unemployment, inflation, exchange rate and interest rates. Speaking of macroeconomic variables, NPLs have a) a negative relationship with economic growth, GDP and stock prices; b) a positive relationship with unemployment and interest rate; c) both positive and negative relationship with inflation and exchange rate. The most common bankspecific determinants are profitability indicators (rate of return on total assets, ROA), cost efficiency, capital adequacy ratio and bank income diversification.

Numerous authors examine the relationship between ROA and NPLs. Those who advocate a negative link between ROA and NPL argue that lower rate of return on an asset may be a reason for banks to engage in riskier business activities (Godlewski, 2008). In the area of lending, this means granting loans to less creditworthy clients, which ultimately increases the share of NPLs in total approved loans. A small number of authors believe in a positive link between ROA and NPLs. When it comes to the impact of cost efficiency on NPLs, a number of authors confirm a negative relationship between variables, noting that higher cost efficiency leads to lower NPLs. When considering the impact of capital adequacy ratios on NPLs, authors are quite divided. Some advocate a negative relationship between the variables and point out that lower capital adequacy ratio can motivate banks to do everything possible to save operations, i.e. they enter into riskier business activities and, thus, approve loans to less creditworthy clients. Some other authors advocate a positive relationship between capital ratio and NPLs and point out that higher capital ratios encourage banks to grant loans to less trustworthy clients (Ryan, 1994). When it comes to the impact of income diversification on NPLs, most authors agree on a negative relationship between variables, so banks 
that, in addition to interest income, generate the so-called non-interest income, have lower NPLs (Ghosh, 2015).

Referring to the Khan et al. (2020) study of NPL determinants in the banking sector of Pakistan in the period 2005-2017, the paper looks at the same variables in order to examine their impact on the emergence of NPLs in the banking sector of the Republic of Serbia in the period from 2010-2019. The research hypothesis is that certain macroeconomic and bank-specific determinants affect the level of NPLs in the banking sector of the Republic of Serbia.

\subsection{Methodology and data}

The conducted analysis includes 7 macroeconomic variables and bank-specific variables. Macroeconomic variables include GDP, inflation rate and unemployment. Bank-specific variables are ROA, cost efficiency, capital adequacy ratio and income diversification. Table 2 shows the variables used.

Table 2: Description of variables

\begin{tabular}{|c|c|c|}
\hline Variable & Definition & Source \\
\hline GDP (GDP) & Real GDP growth & \multirow{3}{*}{$\begin{array}{l}\text { Public Finance Bulletin } \\
\text { (www.mfin.gov.rs) }\end{array}$} \\
\hline Inflation (IN) & $\begin{array}{l}\text { Ratio of current month and } \\
\text { same month of the previous } \\
\text { year }\end{array}$ & \\
\hline Unemployment (UNM) & $\begin{array}{l}\text { Number of jobseekers able } \\
\text { to work in the current } \\
\text { quarter }\end{array}$ & \\
\hline ROA & Net Profit to Total Assets & \multirow{5}{*}{$\begin{array}{c}\text { Banking Sector in Serbia - } \\
\text { Quarterly Reports } \\
\text { (www.nbs.rs) }\end{array}$} \\
\hline Cost efficiency (CE) & $\begin{array}{l}\text { Ratio of non-interest } \\
\text { expenses to non-interest } \\
\text { income }\end{array}$ & \\
\hline CAR & Capital to total assets ratio & \\
\hline Income diversification (ID) & $\begin{array}{l}\text { Ratio of non-interest } \\
\text { income to total income }\end{array}$ & \\
\hline NPL & Share of NPLs in total loans & \\
\hline
\end{tabular}

Source: Authors

Data refers to the banking sector and is given on a quarterly basis. The analysis covers a period of 10 years, from the first quarter of 2010 to the fourth quarter of 2019. The sample contains 40 units and there is no missing data. Data processing uses the R 4.0.2 software package "vars", version 1.5. The following table gives a sample description. 
Table 3: Sample description

\begin{tabular}{|c|c|c|c|c|c|c||}
\hline \hline Variable & Mean & Median & Maximum & Minimum & $\begin{array}{c}\text { Standard } \\
\text { deviation }\end{array}$ & $\begin{array}{c}\text { Number of } \\
\text { observations }\end{array}$ \\
\hline NPL & 310.2 & 342.2 & 438.5 & 101.4 & 108.69 & 40 \\
\hline GDP & 1075543 & 1069503 & 1469840 & 707314 & 174866.8 & 40 \\
\hline IN & 4.405 & 2.550 & 13.600 & 0.500 & 3.847 & 40 \\
\hline UNM & 702.1 & 740.0 & 791.0 & 503.0 & 84.6 & 40 \\
\hline ROA & 1.338 & 1.300 & 2.200 & -0.070 & 0.553 & 40 \\
\hline CE & 1.380 & 1.218 & 2.703 & 1.003 & 0.393 & 40 \\
\hline CAR & 20.96 & 21.07 & 23.70 & 16.40 & 1.704 & 40 \\
\hline ID & 0.7012 & 0.7827 & 0.8818 & 0.3289 & 0.185 & 40 \\
\hline
\end{tabular}

Source: Authors

Figure 3 shows the movement of variables in the observed period. It shows NPL growth until the $25^{\text {th }}$ quarter $\left(1^{\text {st }}\right.$ quarter of 2017), followed by a drastic decline. Unemployment goes the same way. GDP has a relatively stable growth in the observed period, while the capital adequacy ratio reaches its minimum value in the $15^{\text {th }}$ quarter ( $3^{\text {rd }}$ quarter of 2014), after which it records growth. Around the $15^{\text {th }}$ quarter, efficiency records a sharp jump, simultaneously with a drop in ROA.

\section{Figure 3: Movement of variables in the observed period}
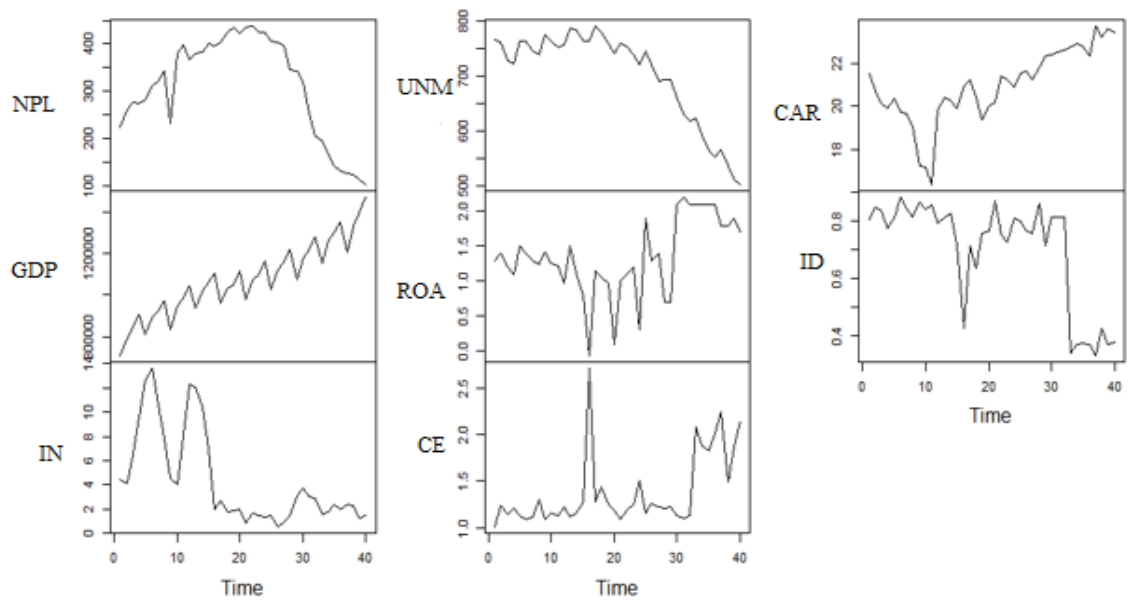

Source: Authors

We use the ADF test (Augumented Dickey-Fuller test) to test the stationarity of variables, where the null hypothesis H0 reads: The time series is not stationary. The ADF test results covering all variables are shown in Table 4. Column $\mathrm{p}$ shows that inflation, ROA and efficiency reject the null hypothesis, which is not true with other variables. Therefore, we carry out the first-order differentiation of NPL, 
GDP, unemployment, CAR and diversification time series, after which the ADF test starts again. The repeated test on the transformed data shows that the time series are stationary $(\mathrm{p}<0.05)$, so the analysis continues using the transformed data.

Table 4: ADF test results

\begin{tabular}{|c|c|c|c|c|c||}
\hline \multirow{2}{*}{ Variable } & \multirow{2}{*}{ Lag } & \multicolumn{2}{|c|}{ Original data } & \multicolumn{2}{c||}{ Differentiated series } \\
\cline { 3 - 6 } & & $\mathrm{t}$ & $\mathrm{p}$ & $\mathrm{t}$ & $\mathrm{p}$ \\
\hline NPL & 1 & 0.143 & 0.7180 & -4.6800 & 0.0004 \\
\hline GDP & 1 & -0.387 & 0.7015 & -6.6600 & 0.0000 \\
\hline IN & & -2.796 & 0.0084 & & \\
\hline UNM & 1 & 1.070 & 0.2920 & -7.1060 & 0.0000 \\
\hline ROA & & -2.262 & 0.0300 & & \\
\hline CE & & -2.091 & 0.0438 & & \\
\hline CAR & 1 & -1.130 & 0.2660 & -4.5700 & 0.0000 \\
\hline ID & 1 & -1.079 & 0.2880 & -5.1200 & 0.0000 \\
\hline
\end{tabular}

Source: Authors

Although most research on credit risk determinants is based on the application of dynamic panel models, due to no data on gross NPLs for individual banks, we apply multiple linear regression model. To check the impact of GDP, inflation, unemployment, ROA, cost efficiency, CAR and diversification on NPLs, we carry out multiple linear regression. The dependent variable is NPL, while the independent variables are GDP, inflation, unemployment, ROA, efficiency, CAR, diversification and IFRS. IFRS is an artificial (dummy) variable with a value of 1 in 2018 and 2019, and 0 in other years. We introduce it into the model to reflect the 2018 change in the banking sector reporting system and its shift to international financial reporting standards.

The results of regression parameter estimates are shown in Table 5. Predictor variables explain $12.1 \%$ of the NPL variation (criterion variables). The model is not significant, $R 2=0.121, F(8,30)=0.52, p=0.84$.

Table 5: Regression parameter estimates

\begin{tabular}{|c|c|c|c|c||}
\hline Coefficient & $\mathrm{b}$ & $\mathrm{SE}$ & $\mathrm{t}$ & $\mathrm{p}$ \\
\hline Constant & 20.58 & 5.667 & 0.363 & 0.719 \\
\hline GDP & 0.00001 & 0.0001 & 0.771 & 0.447 \\
\hline IN & 1.534 & 2.064 & 0.774 & 0.463 \\
\hline UNM & 0.1419 & 0.6138 & 0.231 & 0.819 \\
\hline ROA & -16.09 & 16.53 & -0.973 & 0.338 \\
\hline CE & -8.728 & 32.75 & -0.266 & 0.792 \\
\hline CAR & -5454 & 8.154 & -0.669 & 0.509 \\
\hline ID & -27.83 & 66.35 & -0.419 & 0.678 \\
\hline MSFI & 10.61 & 33.62 & 0.316 & 0.754 \\
\hline
\end{tabular}


As no regression coefficient is statistically significant, we use vector autoregressive analysis (VAR) to test the hypothesis. The difference between regression and the VAR model is that regression uses data covering the same time period, and the VAR model looks for a relationship between the dependent variable and the independent variables from previous periods. Therefore, it makes sense for the regression model to be non-significant and the VAR significant.

VAR models are designed to detect relationships between variables by taking time into account. This means that they observe the model dynamics and the first step in the analysis is always to determine the time lag, which gives the answer to the question: How long should the dependent variable react to changes in the independent variable?

\subsection{Selection of the optimal time lag of variables}

In order to choose the optimal time lag, we test models with a lag of up to a maximum of 3 quarters. A larger lag is not possible due to the short time series relative to the number of variables. We observe the following criteria: Akaike information criterion (AIC), Hannan-Quinn information criterion (HQ), Schwartz information criterion (SC) and Final Prediction Error (FPE). Table 6 shows the values of individual criteria for 3 lags. An asterisk indicates the optimal lag according to a given criterion.

Table 6: Selection of the optimal time lag of model variables

\begin{tabular}{||c|c|c|c|c||}
\hline \hline & AIC(n) & HQ(n) & SC(n) & FPE(n) \\
\hline 1 & $2.64 \mathrm{E}+01$ & $2.75 \mathrm{E}+01$ & $2.96 \mathrm{E}+01$ & $3.30 \mathrm{E}+11$ \\
\hline 2 & $2.39 \mathrm{E}+01$ & $2.59 \mathrm{E}+01$ & $2.98 \mathrm{E}+01$ & $4.38 \mathrm{E}+10$ \\
\hline 3 & $1.86 \mathrm{E}+01 *$ & $2.16 \mathrm{E}+01^{*}$ & $2.74 \mathrm{E}+01^{*}$ & $1.53 \mathrm{E}+09^{*}$ \\
\hline
\end{tabular}

Source: Authors

The results of the analysis suggest a model with a lag of 3 quarters, observed according to all applied criteria.

\subsection{Dijagnostic tests}

Further testing requires residual with normal distribution and with no serial correlation. Therefore, we perform corresponding tests.

Residual normality test: We test univariate and multivariate residual normality of time series using Jarque-Bera univariate and multivariate normality tests. The test results are shown in Table 7 and show that, except for efficiency and diversification, all residuals are normally distributed at a significance level of $95 \%$. There is also a multivariate residual normality. 
Table 7. Results of Jarque-Bera univariate and multivariate residual normality tests

\begin{tabular}{||c|c|c|c||}
\hline Variable & Normality & Skewness & Kurtosis \\
\hline NPL & $\begin{array}{c}\mathrm{X} 2(2)=4.2621 ; \\
\mathrm{p}=0.1187\end{array}$ & & \\
\hline GDP & $\begin{array}{c}\mathrm{X} 2(2)=1.5254 ; \\
\mathrm{p}=0.4664\end{array}$ & & \\
\hline IN & $\begin{array}{c}\mathrm{X} 2(2)=2.4731 ; \\
\mathrm{p}=0.2904\end{array}$ & & \\
\hline UNM & $\begin{array}{c}\mathrm{X} 2(2)=3.6345 ; \\
\mathrm{p}=0.1625\end{array}$ & & \\
\hline ROA & $\begin{array}{c}\mathrm{X} 2(2)=0.5862 ; \\
\mathrm{p}=0.7460\end{array}$ & & \\
\hline CE & $\begin{array}{c}\mathrm{X} 2(2)=96.895 ; \\
\mathrm{p}=0.0000\end{array}$ & & \\
\hline CAR & $\begin{array}{c}\mathrm{X} 2(2)=0.4385 ; \\
\mathrm{p}=0.8031\end{array}$ & & \\
\hline ID & $\begin{array}{c}\mathrm{X} 2(2)=7.2035 ; \\
\mathrm{p}=0.0273\end{array}$ & & \\
\hline Multivariate & $\begin{array}{c}\mathrm{X} 2(16)=12.151 ; \\
\mathrm{p}=0.7335\end{array}$ & $\begin{array}{c}\mathrm{X} 2(8)=9.3381 ; \\
\mathrm{p}=0.3146\end{array}$ & $\begin{array}{c}\mathrm{X} 2(8)=2.8131 ; \\
\mathrm{p}=0.9455\end{array}$ \\
\hline
\end{tabular}

Source: Authors

Serial correlation of residual: To test the autocorrelation of residuals, we use the Portmanteau test, which tests the null hypothesis H0: There is no serial correlation of residuals. The obtained statistic value of $\chi^{2}(832)=1287.7 ; p$ $<0.0001$ means that the null hypothesis can be rejected, i.e. that there is autocorrelation of residuals.

\subsection{Granger causality test}

The cause-and-effect relationships between the variables are analyzed using the Granger causality test. Table 8 shows the test results for each variable separately, with a lag of 3 quarters. Significant causal relationships are marked with an asterisk at the $95 \%$ significance level.

Granger-causality is a way to establish that the variable $\mathrm{X}$ (independent, the one that granger-causes) in the past contains some information that helps predict the current value of the dependent variable Y. As the paper examines the determinants that cause NPL, the F test results in the first column are significant. Based on the test results, we conclude that NPL granger-causes unemployment and capital adequacy ratio. Other variables are not significant. According to test results, NPL granger-causes unemployment. GDP granger-causes inflation and ROA. Inflation granger-causes efficiency. Unemployment granger-causes NPL, GDP, inflation and ROA. ROA granger-causes GDP and unemployment. Efficiency granger-causes ROA, and CAR granger-causes NPL. 
Table 8: Granger-causal relationships between variables

\begin{tabular}{|c|c|c|c|c|c|c|c|c|}
\hline & \multicolumn{8}{|c|}{ Dependent variable } \\
\hline Regressor & NPL & GDP & $\mathrm{IN}$ & UNM & ROA & $\mathrm{CE}$ & CAR & ID \\
\hline NPL & - & $\begin{array}{l}F=2.0349 \\
p=0.1309\end{array}$ & $\begin{array}{l}F=0.6817 \\
p=0.5704\end{array}$ & $\begin{array}{c}\mathrm{F}=6.3398 \\
\mathrm{p}=0.0019 \\
*\end{array}$ & $\begin{array}{l}F=0.241 \\
p=0.867\end{array}$ & $\begin{array}{l}F=0.1669 \\
p=0.9178\end{array}$ & $\begin{array}{c}\mathrm{F}=0.9883 \\
\mathrm{p}=0.412\end{array}$ & $\begin{array}{l}F=0.2953 \\
p=0.8284\end{array}$ \\
\hline GDP & $\begin{array}{l}\mathrm{F}=0.2442 \\
\mathrm{p}=0.8648\end{array}$ & - & $\begin{array}{c}\mathrm{F}=3.8222 \\
\mathrm{p}=0.0201 \\
*\end{array}$ & $\begin{array}{l}F=1.4608 \\
p=0.2457\end{array}$ & $\begin{array}{c}\mathrm{F}=4.9167 \\
\mathrm{p}=0.0070 \\
*\end{array}$ & $\begin{array}{c}F=0.063 \\
p=0.9789\end{array}$ & $\begin{array}{l}F=0.7467 \\
p=0.5331\end{array}$ & $\begin{array}{c}\mathrm{F}=0.4532 \\
\mathrm{p}=0.717\end{array}$ \\
\hline IN & $\begin{array}{c}\mathrm{F}=0.824 \\
\mathrm{p}=0.4914\end{array}$ & $\begin{array}{l}F=0.0822 \\
p=0.9692\end{array}$ & - & $\begin{array}{l}F=0.1755 \\
p=0.9121\end{array}$ & $\begin{array}{l}F=0.4267 \\
p=0.7353\end{array}$ & $\begin{array}{c}\mathrm{F}=3.1608 \\
\mathrm{p}=0.0394 \\
*\end{array}$ & $\begin{array}{l}F=2.8075 \\
p=0.0571\end{array}$ & $\begin{array}{r}\mathrm{F}=0.959 \\
\mathrm{p}=0.4252\end{array}$ \\
\hline UNM & $\begin{array}{c}\mathrm{F}=10.268 \\
\mathrm{p}=0.0001 \\
*\end{array}$ & $\begin{array}{c}\mathrm{F}=33.222 \\
\mathrm{p}<0.0001 \\
*\end{array}$ & $\begin{array}{c}\mathrm{F}=4.7717 \\
\mathrm{p}=0.0080 \\
*\end{array}$ & - & $\begin{array}{c}\mathrm{F}=5.1779 \\
\mathrm{p}=0.0055 \\
*\end{array}$ & $\begin{array}{l}F=1.0769 \\
p=0.3743\end{array}$ & $\begin{array}{l}F=1.0016 \\
p=0.4061\end{array}$ & $\begin{array}{l}F=0.0805 \\
p=0.9701\end{array}$ \\
\hline ROA & $\begin{array}{l}F=1.4325 \\
p=0.2535\end{array}$ & $\begin{array}{c}\mathrm{F}=4.1189 \\
\mathrm{p}=0.0150 \\
*\end{array}$ & $\begin{array}{c}\mathrm{F}=0.6035 \\
\mathrm{p}=0.618\end{array}$ & $\begin{array}{c}\mathrm{F}=6.5808 \\
\mathrm{p}=0.0016 \\
*\end{array}$ & - & $\begin{array}{c}F=0.692 \\
p=0.5644\end{array}$ & $\begin{array}{l}F=1.3081 \\
p=0.2907\end{array}$ & $\begin{array}{c}\mathrm{F}=1.1254 \\
\mathrm{p}=0.355\end{array}$ \\
\hline $\mathrm{CE}$ & $\begin{array}{l}\mathrm{F}=0.8086 \\
\mathrm{p}=0.4994\end{array}$ & $\begin{array}{l}\mathrm{F}=1.5825 \\
\mathrm{p}=0.2149\end{array}$ & $\begin{array}{l}F=0.5134 \\
p=0.6762\end{array}$ & $\begin{array}{l}F=1.1009 \\
p=0.3646\end{array}$ & $\begin{array}{c}\mathrm{F}=3.6934 \\
\mathrm{p}=0.0229 \\
*\end{array}$ & - & $\begin{array}{l}F=0.6257 \\
p=0.6042\end{array}$ & $\begin{array}{l}\mathrm{F}=0.9813 \\
\mathrm{p}=0.4152\end{array}$ \\
\hline CAR & $\begin{array}{c}\mathrm{F}=4.2597 \\
\mathrm{p}=0.0131 \\
*\end{array}$ & $\begin{array}{l}F=1.5592 \\
p=0.2205\end{array}$ & $\begin{array}{c}\mathrm{F}=1.225 \\
\mathrm{p}=0.3184\end{array}$ & $\begin{array}{l}F=1.7574 \\
p=0.1773\end{array}$ & $\begin{array}{l}F=0.6932 \\
p=0.5637\end{array}$ & $\begin{array}{c}\mathrm{F}=0.3254 \\
\mathrm{p}=0.807\end{array}$ & - & $\begin{array}{l}F=0.5628 \\
p=0.6439\end{array}$ \\
\hline ID & $\begin{array}{l}\mathrm{F}=1.5495 \\
\mathrm{p}=0.2229\end{array}$ & $\begin{array}{l}\mathrm{F}=0.2504 \\
\mathrm{p}=0.8604\end{array}$ & $\begin{array}{l}\mathrm{F}=0.1589 \\
\mathrm{p}=0.9231\end{array}$ & $\begin{array}{l}\mathrm{F}=0.3018 \\
\mathrm{p}=0.8238\end{array}$ & $\begin{array}{l}\mathrm{F}=1.7003 \\
\mathrm{p}=0.1888\end{array}$ & $\begin{array}{l}\mathrm{F}=0.7836 \\
\mathrm{p}=0.5128\end{array}$ & $\begin{array}{l}\mathrm{F}=0.3375 \\
\mathrm{p}=0.7983\end{array}$ & - \\
\hline
\end{tabular}

Source: Authors

The multivariate Granger test examines the cause-and-effect relationship between GDP, inflation, unemployment, ROA, efficiency, CAR, and diversification as independent variables, and NPL as dependent variable, with a 3quarter lag. The null hypothesis that there is no granger-causality between these two sets of variables is tested. Based on the calculated statistics F $(21.88)=1.9124$; $\mathrm{p}=0.01934$, we can reject the null hypothesis, i.e. that GDP, inflation, unemployment, ROA, efficiency, CAR and diversification granger-cause NPLs.

\subsection{Variance decomposition and impulse response function}

Variance decomposition is a way to identify the degree to which variance of dependent variable in earlier periods affects variance in the current period. Also, variance decomposition shows the degree to which variance of independent variables affects variance of dependent variable. This helps determine the structure of the influence on dependent variable and the main causes of changes in the dependent variable.

Figure 4 shows the structure of variance of 8 variables over a prediction period of 24 quarters. 
Figure 4: Variance decomposition

FEVD for GDP

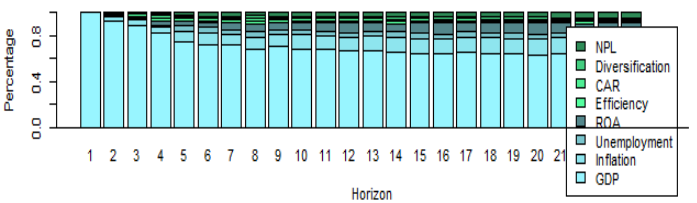

Horizo

FEVD for Inflation

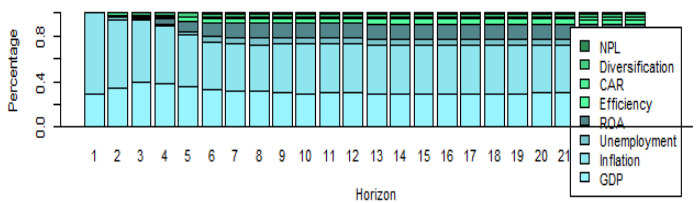

FEVD for Unemployment

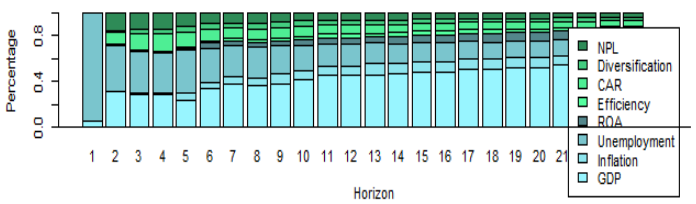

FEVD for ROA

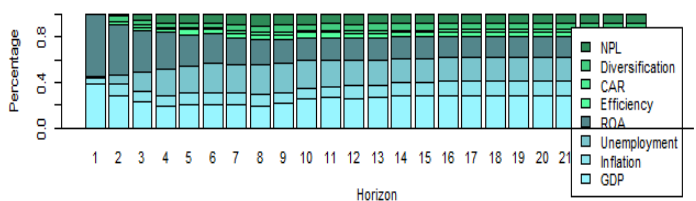

FEVD for Efficienc

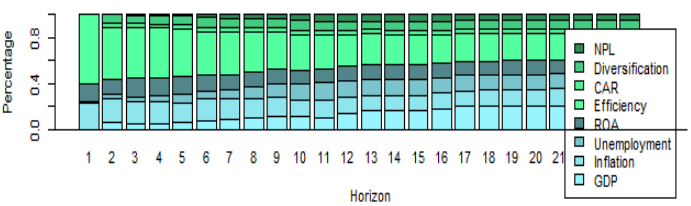

FEVD for CAR

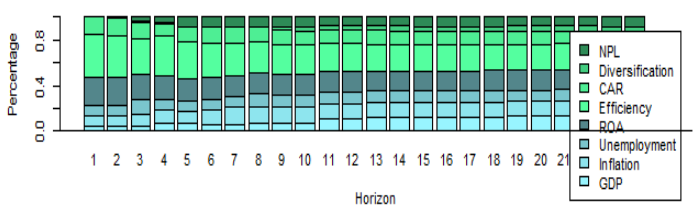

FEVD for Diversification

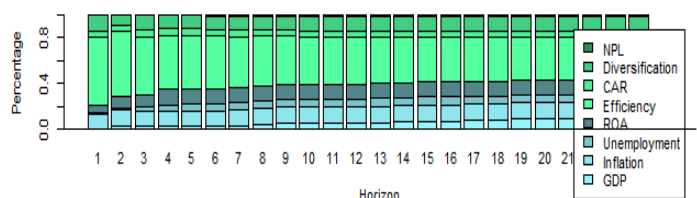

FEVD for NPL

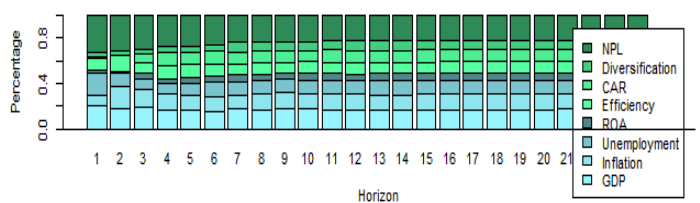

Source: Authors

Each column represents one prediction period. In our case, it is a quarter, and the prediction horizon is 24 quarters, i.e. 6 years. The columns are divided into 8 painted parts, according to the legend. Each column provides an answer to the question: What percentage of the dependent variable variance is, in a given quarter after the initial shock, explained by each of the independent variables?

Variance decomposition and response function are very similar measures and refer to the prediction obtained from the model. Response function observes the next-period movement of variable, while variance structure is presented in the variance decomposition diagram. For each variable (if viewed as dependent), the diagram shows other variables that affect its variance (dependent variable).

In the context of this paper, it is important to consider the impact of other variables on NPLs as a dependent variable. In that sense, the analysis focuses on 
the last diagram in the lower right corner. The diagram shows that in the first period, the greatest influence on NPL variance comes from the NPL itself from the previous period, and that influence decreases until the $7^{\text {th }}$ quarter, after which it remains constant. The impact of ROA and GDP is significant in the first period, but the impact of ROA subsequently decreases, while the impact of GDP remains at approximately the same level throughout the prediction period. After a relatively small impact at start, the impact of other variables stabilizes after 6 quarters.

Impulse response (IRF) function is used to describe the response of model variables to a sudden change in one or more variables. These diagrams refer to future periods. The IRF shows how dependent variable behaves in the following period (in our case, 24 quarters) if independent variable changes by 1 standard deviation. This initial impulse does not have to occur in the first period after the period analyzed, but the diagram presents a generic pattern of behavior, i.e. "shock" can happen at any time in the future. The response of NPLs to changes in GDP, inflation, unemployment, ROA, efficiency, CAR and diversification by 1 standard deviation is shown in the following graphs.

Figure 5: NPL response to change in GDP

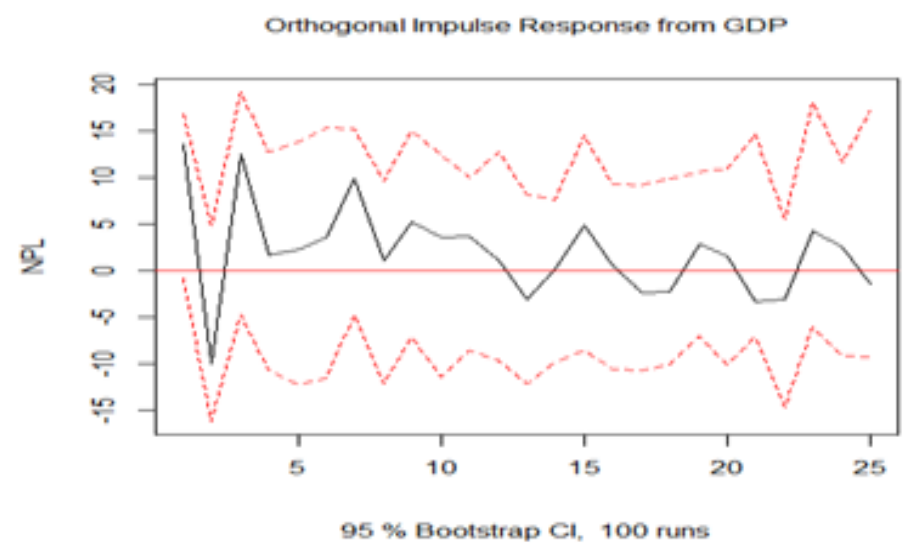

Source: Authors

Figure 5 shows that the change in GDP by 1 standard deviation causes a change in NPL in all 24 periods, with the change being greatest in the first 4 periods. 
Figure 6: NPL response to inflation changes

Orthogonal Impulse Response from Inflation

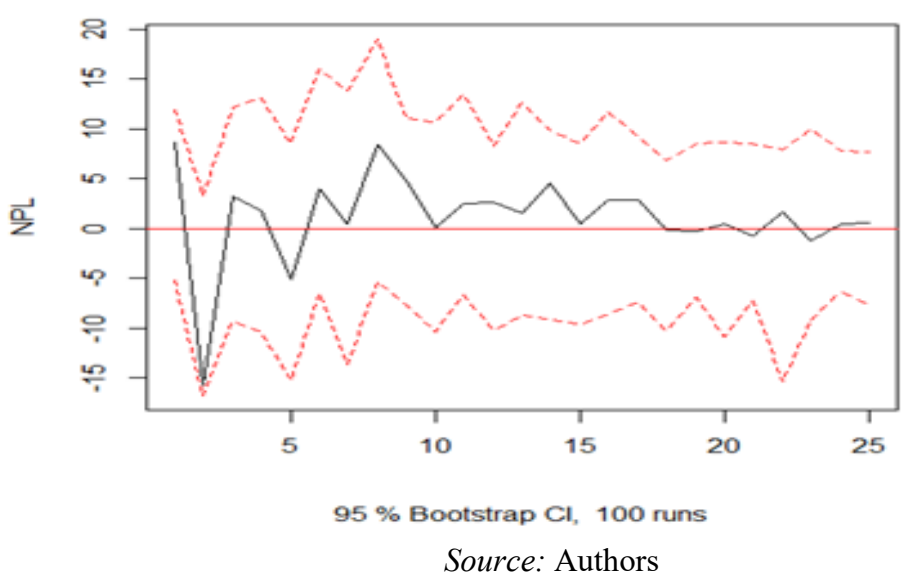

The figure shows that the change in the inflation rate by 1 standard deviation leads to the instability of NPL in the first 8 periods, after which the effect of the change is gradually lost.

Figure 7: NPL response to changes in unemployment

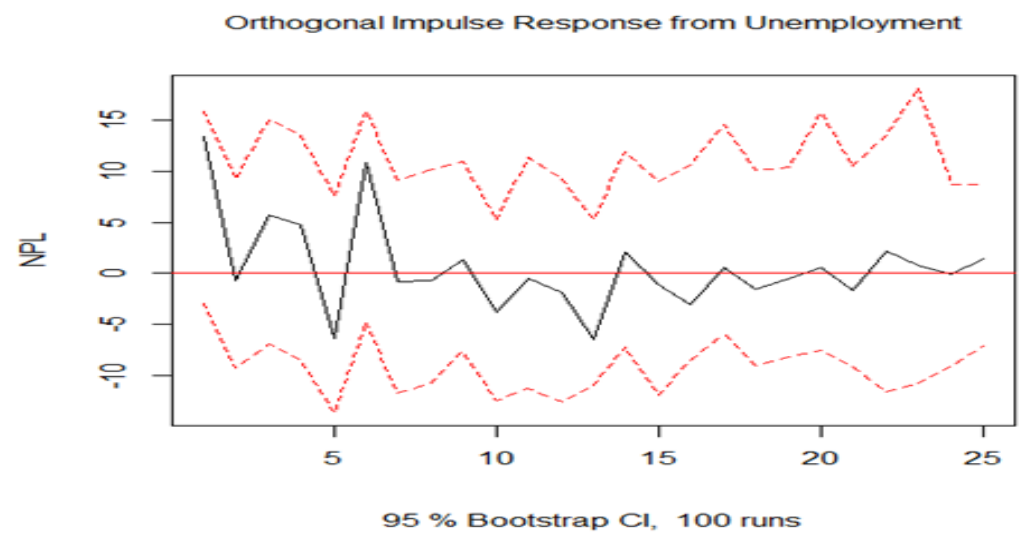

Source: Authors

The change in unemployment by 1 standard deviation leads to the instability of NPL in the next 6 periods, after which the effect of the change is gradually lost. 
Figure 8: NPL response to ROA change

Orthogonal Impulse Response from ROA

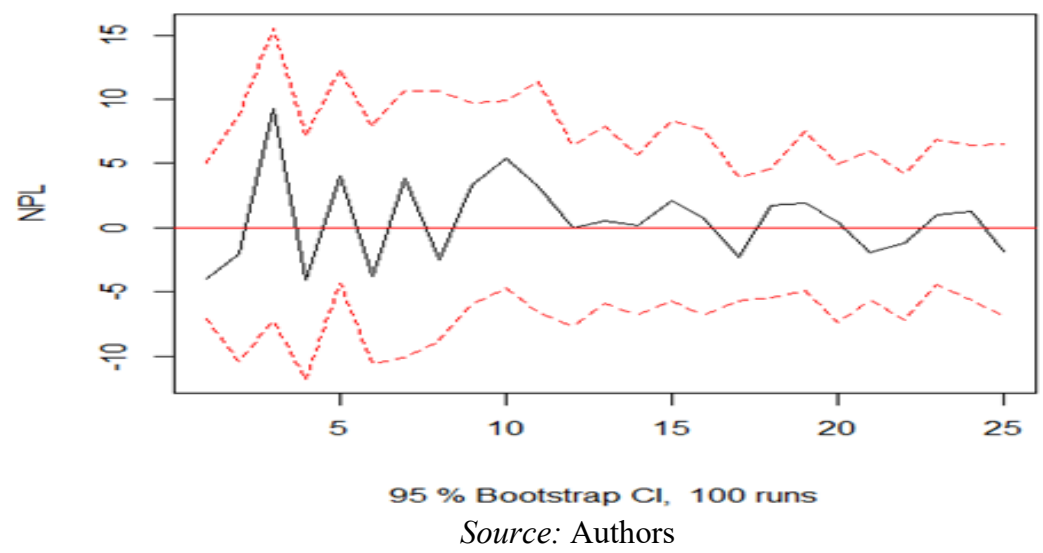

The figure shows that the effect of ROA change by 1 standard deviation on NPL is strongest in the first 11 periods after the shock, while the effects are lost thereafter.

Figure 9: NPL response to a change in cost efficiency

Orthogonal Impulse Response from Efficiency

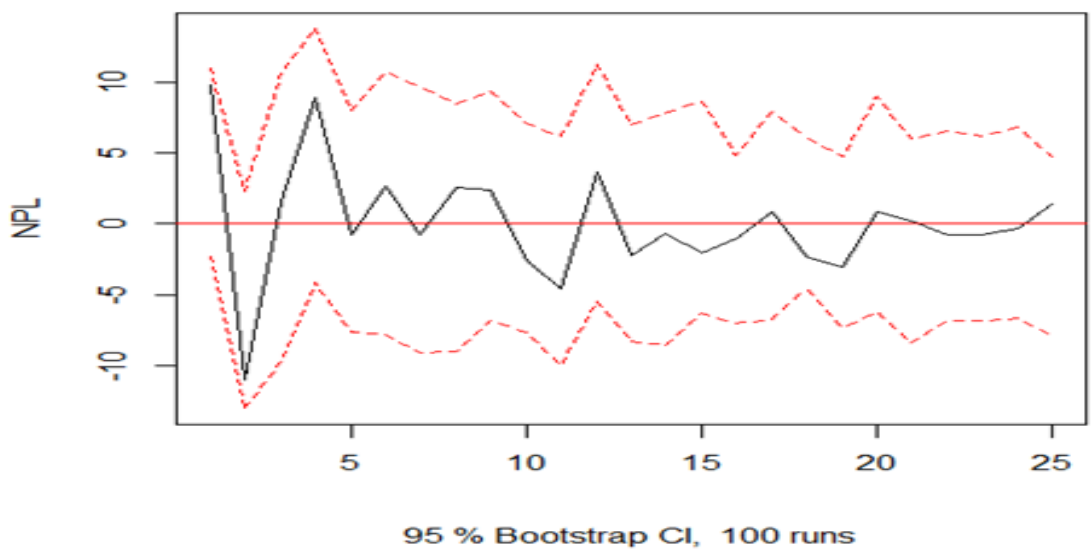

Source: Authors

The effect of efficiency change on NPL is lost after 12 periods. 
Figure 10: NPL response to a change in capital adequacy ratio

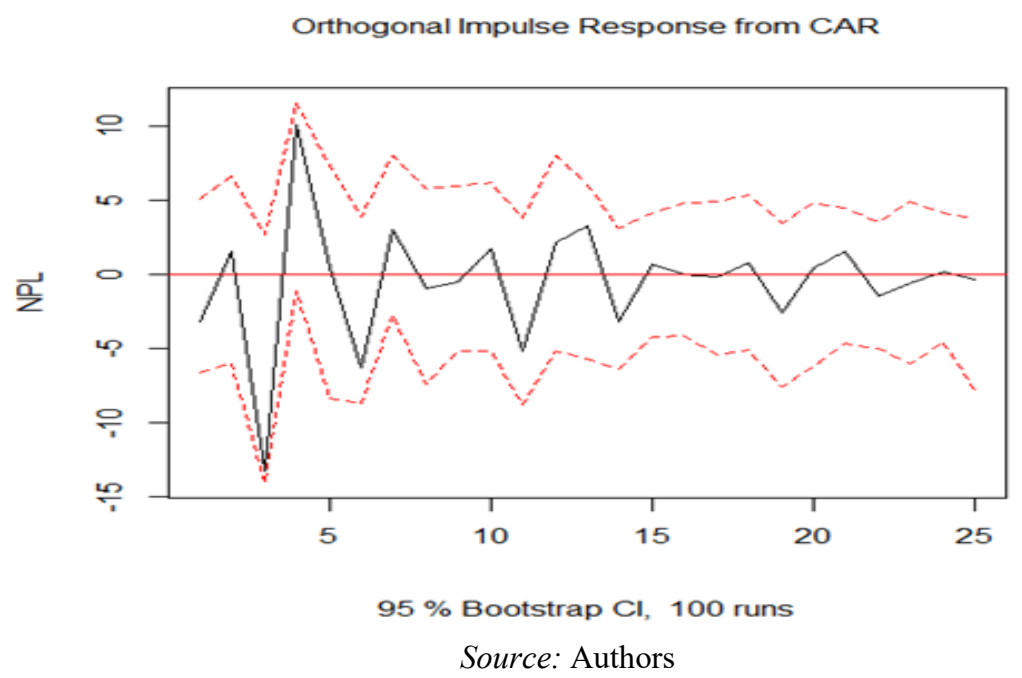

The effect of change in the capital adequacy ratio is strongest in the first 7 quarters after the initial shock, while it slowly disappears later.

Figure 11: NPL response to change in income diversification Orthogonal Impulse Response from Diversification

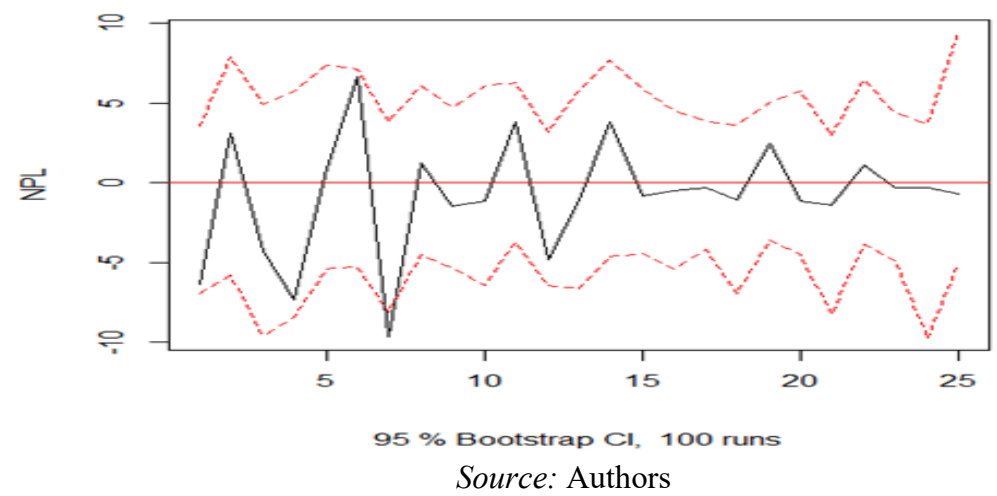

The effects of changes in income diversification indicators on NPLs are strongest in the first 14 quarters, after which they are gradually lost. 


\section{Conclusion}

Analysis of NPLs and their and trends in the banking sector of the Republic of Serbia in the period from 2010-2019 shows that the domestic banking sector in the first years of the analyzed period was burdened with significant NPL rates. The growth of the share of non-performing in total loans at the sector level was present until the end of 2015, when it reached as much as $22.64 \%$. After that, the share of NPLs in total approved loans gradually decreased, so, at the end of the observed period, i.e. in the IV quarter of 2019, it amounted to just over 4\%. Assessing a bank's exposure to credit risk requires additional analysis of NPLs in relation to value adjustments, regulatory provisions and capital, which can ultimately assess the banking sector's ability to absorb losses arising from NPLs. In any case, NPLs generate huge losses for individual banks and the sector as a whole, as a result of which numerous studies focus on identifying NPL determinants.

The paper analyzed the impact of certain macroeconomic and bank-specific NPL determinants in the banking sector of the Republic of Serbia. 7 variables were tested, 3 in the group of macroeconomic variables (GDP, inflation rate and unemployment) and 4 in the group of bank-specific variables (ROA, cost efficiency, capital adequacy ratio and income diversification). Due to the lack of data on the share of NPLs in total loans at the level of individual banks, for the purposes of the analysis, the multiple linear regression model was first applied. As the regression coefficients are not statistically significant, the VAR model was used to analyze the influence of independent variables on NPL. The results showed that unemployment from the previous period, capital adequacy ratio two periods earlier and NPLs from the previous period affect NPL in the current period. The multivariate Granger test confirmed the cause-and-effect relationship between GDP, inflation, unemployment, ROA, efficiency, capital adequacy ratios, and income diversification as independent variables, and NPLs as dependent variable, with a 3-quarter lag.

\section{References}

ECB (2020) Preuzeto sa: https://www.bankingsupervision.europa.eu/about/ ssmexplained/html/npl.en.html, pristupljeno: 31. Oktobar 2020.

ECB (2017). Guidance to banks on non-performing loan, Preuzeto sa https://www.bankingsupervision.europa.eu/ecb/pub/pdf/guidance_on_npl.en.pdf.

Ghosh, A. (2015). Banking-industry specific and regioinal economic determinants of nonperforming loans: evidence from US states. Journal of Financial Stability, 20, 93-104.

Godlewski, C. (2008). Bank capital and credit risk taking in emerging market economies. Journal of Banking REgulation, 6(2), 128-145.

Khan, M., Siddique, A., \& Sarwar, Z. (2020). Determinants of non-performing loans in the banking sector in developing state. Asian Journal of Accounting Research, 5(1), 135145. 
NBS (2011). Kontrola poslovanja banaka - Izveštaj za IV tromesečje 2011. godine. Preuzeto sa https://www.nbs.rs/export/sites/NBS_site/documents/kontrola-

banaka/kvartalni_izvestaj_IV_11.pdf.

NBS (2013). Bankarski sektor u Srbiji - Izveštaj za IV tromesečje 2012. godine. Preuzeto sa https://www.nbs.rs/export/sites/NBS_site/documents/kontrolabanaka/kvartalni_izvestaj_IV_12.pdf.

NBS (2014-2019). Statistički aneks - IV tromesečje. Preuzeto sa https://www.nbs.rs/sr_RS/finansijske-institucije/banke/izvestaji-i-analize/

NBS (2020). Bankarski sektor u Srbiji - Izveštaj za IV tromesečje 2019. godine. Preuzeto sa https://www.nbs.rs/export/sites/NBS_site/documents/kontrolabanaka/kvartalni_izvestaj_IV_19.pdf

Nikolopoulos, K., \& Tsalas, A. (2017). Non-performing Loans: A Review of the Literature and the International Experience. U P. Monokroussos, \& C. Gortsos, Non-Performing Loans and Resolving Private Sector Insolvency: Experiences from the EU Periphery and the Case of Greece (str. 47-68). Palgrave Macmillan.

Račić, Ž., \& Barjaktarović, L. (2016). Analiza empirijskih determinanti kreditnog rizika u bankarskom sektoru Republike Srbije. Bankarstvo, 45(4), 94-109.

Rajan, R. (1994). Why bank credit policies fluctuate. Quarterly Journal of Economics, 2(109), 399-441.

Udruženje banaka Srbije (2017). Bankarski sektor Srbije u 2017. godini. Preuzeto sa https:/www.ubs-asb.com/files/Analize/Analiza2017.pdf

\section{ANALIZA DETERMINANTNI PROBLEMATIČNIH KREDITA U BANKARSKOM SEKTORU REPUBLIKE SRBIJE}

Apstrakt: Nakon finansijske deregulacije koja je obeležila poslednje dve decenije 20. veka, banke su izgubile monopolsku poziciju i suočile se sa brojnim konkurentima na tržištu finansijskih usluga. Boreći se za svoj tržišni udeo, banke su počele da odobravaju kredite po relaksiranim kreditnim uslovima. Ovakva njihova politika rezultirala je porastom udela problematičnih, odnosno neperformansnih kredita (NPLs) i u konačnom uticala na povećanje kreditnog rizika u bankarskom sektoru. Udeo neperformansnih kredita u ukupnim kreditnim plasmanima ukazuje na kvalitet bankarske aktive, usled čega je analiza njihovog stanja i kretanja važan parametar pri oceni stabilnosti bankarskog i ukupnog finansijskog sektora. Rad ima za cilj da kroz analizu kretanja NPL u bankarskom sektoru Republike Srbije u periodu 2010-2019. godina identifikuje determinante koje su značajno uticale na razmere kreditnog rizika. Za potrebe istraživanja korišćen je vektorski autoregresioni model (VAR), a rezultati su potvrdili da bruto-domaći proizvod, inflacija, nezaposlenost, stopa prinosa na ukupnu aktivu (ROA), operativna efikasnost, stopa adekvatnosti kapitala i diverzifikacija prihoda utiču na NPL. Analiza je pokazala da je nivo problematičnih kredita uslovljen dejstvom brojnih faktora, kako makroekonomskih, tako i onih koji su specifični za bankarsko poslovanje, a koje regulatorni organi moraju imati u vidu pri oceni kreditnog rizika sa kojim se suočava bankarski sektor.

Ključne reči: NPL, determinante, VAR, bankarski sektor RS 


\section{Authors' biographies}

Kristijan Ristić graduated from the Faculty of Economics, University of Belgrade. He completed his master studies at the Faculty of Management, "Braća Karić" University in Belgrade. Currently, he is a PhD student at the Faculty of Economics, University of Niš, where he passed all the exams and filed his doctoral dissertation application. He has published numerous papers in scientific journals in the fields of Finance and Banking and has participated in various national and international conferences.

Mirjana Jemović is an Assistant Professor at the Faculty of Economics, University of Niš, where she teaches courses on Financial system and financial institutions, Banking management, Financial markets and Global banking. She has published numerous papers in scientific journals in the fields of Finance and Banking and has participated in various national and international conferences in the country and abroad. 